\title{
Advanced Treatment of Coal Chemical Industry Wastewater by Electro-Catalysis with Gd-Doped Ti/SnO 2 Anode
}

\author{
Baolin Hou ${ }^{1 *}$, Renjian Deng¹, Haifeng Zhuang², Yebing Yang ${ }^{3}$ \\ ${ }^{1}$ Hunan Provincial Key Laboratory of Shale Gas Resource Utilization, \\ Hunan University of Science and Technology, Xiangtan, 411201, China \\ ${ }^{2}$ Key Laboratory of Recycling and Eco-treatment of Waste Biomass of Zhejiang Province, \\ Zhejiang University of Science and Technology, Hangzhou, 310023, China \\ ${ }^{3}$ Xiangtan Sewage Treatment Co., Ltd, Xiangtan, 411100, China
}

Received: 17 November 2016

Accepted: 11 January 2017

\begin{abstract}
The preparation of a Gd-doped $\mathrm{Ti} / \mathrm{SnO}_{2}$ anode using the sol-gel method was employed in electrolysis as an advanced treatment of coal chemical industry wastewater. The optimal Gd-doped content and sintering temperature were $2 \%$ and $750^{\circ} \mathrm{C}$. The electro-catalytic performance was enhanced after doping with an adequate amount of Gd. The doped Gd accelerated the generation rate and content of hydroxyl radicals in the electrolysis process. Gd was mixed into the $\mathrm{SnO}_{2}$ lattice by means of displacement to refine the $\mathrm{SnO}_{2}$ crystalline grain. The diminution of grain size supplied more active sites on the electrode surface. The reaction of TOC degradation was between pseudo zero-order and first-order kinetics, and was more inclined to pseudo first-order kinetics. The performance and the stability test demonstrated that the prepared $\mathrm{Ti} / \mathrm{Gd}_{-} \mathrm{SnO}_{2}$ anode was competent and that electrolysis with the anode could serve as a technically feasible method with potential application for the advanced treatment of coal chemical industry wastewater.
\end{abstract}

Keywords: electro-catalysis, $\mathrm{Ti} / \mathrm{SnO}_{2}$ anode, sol-gel, coal chemical industry wastewater

\section{Introduction}

Coal chemical industry effluent was considered to be a kind of refractory industrial wastewater with poor biodegradability [1]. The composition of coal chemical industry wastewater is very complex, containing high concentrations of phenols, tar, polycyclic aromatic hydrocarbons, and ammonia, as well as refractory and

*e-mail: h3i3t0@126.com

toxic compounds such as cyanide and thiocyanate [2]. The traditional activated sludge process was widely used in coal chemical plants for wastewater treatment. However, the content of contaminants in effluent after biological treatment was still high, a great distance between the requirements of zero emission of coal chemical industry wastewater [3]. Therefore, advanced treatment was necessary to further remove the toxic and hazardous pollutants in the effluent.

Although the history of electrochemistry spans more than 200 years, its application in wastewater treatment began only 50 years ago. Electro-catalytic oxidation 
is a new wastewater treatment technology [4]. As an advanced oxidation process (AOP), electro-catalysis has shown great advantages in terms of wastewater treatment, such as satisfactory treatment effect, no derivative pollution and easy automation that is not attached to other technologies [5-6]. Electrochemical advanced oxidation processes (EAOPs) have received great attention for water remediation, especially in the degradation of recalcitrant organic compounds, because they can generate large amounts of hydroxyl radicals $(\cdot \mathrm{OH})$ for an effective and fast mineralization of toxic and hazardous organic contaminants [7-8]. EAOPs have been regarded as an environmentally friendly technology. Both electrochemical combustion (Eq. (1)) and electrochemical conversion (Eq. (2)) of organics contribute to electrocatalytic reactions [9-10]:

$$
\begin{gathered}
\left\{\begin{array}{l}
M O_{x}+z_{2} O-\mathrm{ze}^{-} \rightarrow M O_{x}(\bullet O H \cdot)_{\mathrm{z}}+\mathrm{z} H^{+} \\
R+M O_{x}(\bullet \mathrm{OH} \cdot)_{\mathrm{z}} \rightarrow \mathrm{RO}+M O_{X}
\end{array}\right. \\
\left\{\begin{array}{l}
M O_{x}+z H_{2} O-z e^{-} \rightarrow M O_{x}(\cdot O H)_{\mathrm{z}}+\mathrm{z} H^{+} \\
M O_{x}(\cdot O H)_{\mathrm{z}}-\mathrm{ze}^{-} \rightarrow M O_{\mathrm{x}}-O_{\mathrm{z}}+\mathrm{z} H^{+} \\
M O_{\mathrm{x}}-O_{\mathrm{z}} \rightarrow M O_{\mathrm{x}+\mathrm{z}} \\
R+M O_{\mathrm{x}+\mathrm{z}} \rightarrow R O+M O_{\mathrm{x}}
\end{array}\right.
\end{gathered}
$$

The electrode is the core of electro-catalytic technology in wastewater treatment. Dimension stable anode (DSA) is a type of electrode with a wide application due to its excellent catalytic activity and stability. Various methods for electrode preparation have emerged, such as the impregnation method [11], sol-gel [12], electrodeposition [13], physical vapor deposition, and chemical vapor deposition [14]. Sol-gel is widely used in the preparation of multi-component oxide thin film owing to its high purity, excellent homogeneity, high degree of multi-component scatter, and its easily controlled particle size. The homogeneous dispersion nano oxide layer can be obtained using the sol-gel method.

Rare earth element (REE) shows the ability of catalysis and co-catalysis in many aspects owing to the special $4 \mathrm{f}$ electronic structure, and physical and chemical characteristics [15-16]. Conductivity, oxygen evolution potential, stability, and corrosion resistance of the electrode can be improved by doping REE. Different REEs showed different co-catalysis abilities [15, 17]. REE can also affect the formation and growth of crystallite grain in thermal treatment [18]. Stannic anhydride anodedoped gadolinium ( $\mathrm{Ti} / \mathrm{Gd}-\mathrm{SnO}_{2}$ ) was prepared by the solgel method in this context. Performance of the electrode in advanced treatment of coal chemical industry wastewater was also investigated in terms of COD and chroma removal, and mineralization. Characterization of the anode was obtained with the morphology and component analysis of the electrode surface.

\section{Materials and Methods}

\section{Experimental Apparatus}

The reactor was a one-compartment electrochemical cell made up of power, electrolytic cell, electrodes, and agitator. The cathode was a stainless steel plate. The prepared $\mathrm{Ti} / \mathrm{Gd}-\mathrm{SnO}_{2}$ was employed as the anode. The dimensions of the electrode were $2 \times 4 \mathrm{~cm}$. The electrolytic cell was a cuboid vitreous vessel with an effective volume of $300 \mathrm{ml}$. A constant current was provided by a DC-stabilized power supply (WWL-PS). A magnetic stirrer was equipped with an electrolytic cell to mix the solution. The volume of the reaction solution was $250 \mathrm{ml}$. The current density used in the experiment was fixed at $15 \mathrm{~mA} / \mathrm{cm}^{2}$. Anhydrous sodium sulfate was added as background electrolyte with a concentration of $0.5 \mathrm{~mol} / \mathrm{L}$.

\section{Wastewater Characteristics}

Real coal chemical industry wastewater used in this study was obtained from the full-scale wastewater treatment facility of a coal chemical industry plant in Harbin, China. The wastewater sample was the effluent from the secondary settling tank. The main characteristic parameters are listed in Table 1.

\section{Prepararing the Electrode}

\section{Processing the Support}

A titanium plate served as the support in preparation of the electrode. Prior to the layer deposition, the titanium plate was pretreated. Pretreatment of the titanium plate included polishing the base and acid washing. Polishing the surface was to get rid of the oxide layer with coarse sandpaper, followed with fine sandpaper. Then the titanium board was washed with hot alkaline solution to wipe off oil. Finally, it was rinsed and etched with oxalic acid to remove the oxide film and enhance adhesion between the titanium plate and the coating. The residual oxalic acid was washed off with deionized water. The pretreated titanium substrate was preserved in anhydrous ethanol.

\section{Preparation of the Electrode}

The Gd-SnO, sols were prepared from anhydrous $\mathrm{SnCl}_{4}, \mathrm{SbCl}_{3}, \mathrm{Gd}\left(\mathrm{NO}_{3}\right)_{3}$, water, propanol, and isopropanol in the following molar ratio: $\mathrm{Sn}: \mathrm{Sb}=100: 6.5$. The Gd-doped content (defined as $\mathrm{Gd} / \mathrm{Sn}$ ) was controlled to $1 \%, 2 \%, 3 \%$, and $4 \%$ by adjusting the amount of

Table 1. Main characteristics of the wastewater.

\begin{tabular}{|c|c|c|c|c|c|}
\hline Items & $\begin{array}{c}\text { COD } \\
(\mathrm{mg} / \mathrm{L})\end{array}$ & $\begin{array}{c}\text { TOC } \\
(\mathrm{mg} / \mathrm{L})\end{array}$ & UV254 & $\mathrm{pH}$ & Chroma \\
\hline Mean & 116.51 & 36.29 & 0.948 & 7.18 & 98 \\
\hline
\end{tabular}


$\mathrm{Gd}\left(\mathrm{NO}_{3}\right)_{3}$. The molar ratio of water, propanol, and isopropanol was 3:3:2. The prescribed amount mixture of $\mathrm{SnCl}_{4}, \mathrm{SbCl}_{3}$, and $\mathrm{Gd}\left(\mathrm{NO}_{3}\right)_{3}$ was dissolved in the mixture of solvent and an exothermic reaction took place. Then the solution was stirred for $1 \mathrm{~h}$ to promote the prehydrolysis of the precursor. A certain amount of polyethylene glycol was added as a protective agent to keep from agglomeration. Following the above procedures, clear and homogenous sols were obtained. The sols were painted evenly on the pretreated titanium plate followed by drying at $95^{\circ} \mathrm{C}$. The processes of painting and drying were repeated five times. Then the titanium plate was heated at $350^{\circ} \mathrm{C}$ with a definite annealing temperature for $15 \mathrm{~min}$. We duplicated the whole procedure five times, after which the sample was sintered at a defined temperature with the same annealing temperature for $120 \mathrm{~min} .450,550,650$, and $750^{\circ} \mathrm{C}$ were employed in the sintering process. Following all the above programs, a titanium anode coated with $\mathrm{SnO}_{2}$ doping various amounts of $\mathrm{Gd}$ was obtained using the sol-gel method. The active material $\left(\mathrm{SnO}_{2}\right)$ deposited was about $1.0 \mathrm{mg} / \mathrm{cm}^{2}$, calculated by weight difference before and after the preparation procedure and the area of the titanium substrate.

\section{Analytical Methods}

Samples were taken from the reactor at constant intervals and analyzed immediately after being filtered through $0.45 \mu \mathrm{m}$ filter paper. COD and chroma were measured in accordance with standard methods. Total organic carbon (TOC) was measured by a TOC analyzer (TOC-CPN, Shimadzu, Japan). UV254 was determined with a UV-Vis spectrophotometer (UV-2550). SEM analysis was performed on a field emission scanning electron microscope (Helios Nanolab600i). XRD spectrum was record on a D/max-rb x-ray diffractometer. Test conditions were: $\mathrm{CuK} \alpha(0.15405 \mathrm{~nm}), 45 \mathrm{kV}$, $50 \mathrm{~mA}$, graphite monochromator, slit DS $1^{\circ} \mathrm{SS} 1^{\circ} \mathrm{RS}$ $0.15 \mathrm{~mm}$. Fluorescence spectrum was conducted on an RF-6500 fluorescence spectrometer. The polarization curve was recorded on a CHI 832 electrochemical station (CHI Inc., USA) with a single component cell. Pt foil was used as the counter electrode and an $\mathrm{Ag} / \mathrm{AgCl}$ (saturated $\mathrm{KCl}$ ) electrode as the reference electrode. The working electrode was the prepared anode constituting a triple electrode system. Test dynamic potential scan rate was $10 \mathrm{mV} / \mathrm{s}$.

\section{Results and Discussion}

\section{Effect of Preparation Process on Electro-Catalytic Performance}

\section{Sintering Temperature}

Anodes prepared at various heating temperatures were applied in advanced treatment of coal chemical industry wastewater. $\mathrm{Gd}$ doping content $(\mathrm{Gd} / \mathrm{Sn})$ was

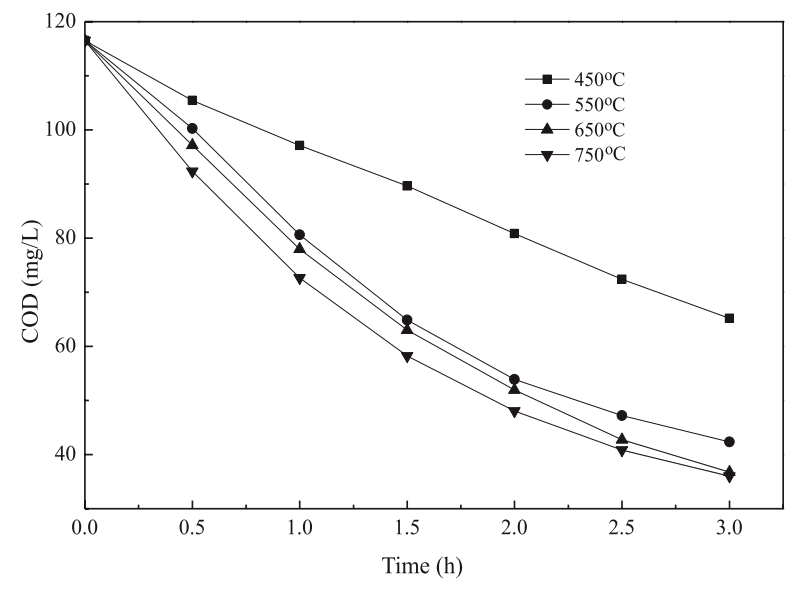

Fig. 1. The effect of sintering temperature on electro-catalytic performance.

kept at $4 \%$. Chemical oxygen demand (COD) was employed to characterize the electro-catalytic performance.

The electro-catalytic performance was poor when heating temperature was $450^{\circ} \mathrm{C}$ (Fig. 1). The effluent COD was $65.18 \mathrm{mg} / \mathrm{L}$ for $3 \mathrm{~h}$ electrolysis, with the removal efficiency of only $44.05 \%$. The electro-catalytic capability was enhanced when heating temperature rose to $550^{\circ} \mathrm{C}$, with $\mathrm{COD}$ removal efficiency increasing to $63.66 \%$. COD removal efficiency was comparable to the anodes heated at $650^{\circ} \mathrm{C}$ and $750^{\circ} \mathrm{C}$, while the latter was a little higher. The growth of $\mathrm{SnO}_{2}$ crystal was incomplete at lower heating temperatures, causing few amount of carrier-generated electro-catalysis, high resistance, and poor conductivity. Therefore, electro-catalytic performance of the anode was poor. Higher temperature was in favor of the formation and growth of $\mathrm{SnO}_{2}$ crystals, inducing better electro-catalytic activity.

\section{Gd Doping Content}

We investigated electro-catalytic performances of anodes doped in different amounts of Gd heated at $750^{\circ} \mathrm{C}$.

The electro-catalytic performances of anodes with various Gd doping contents varied significantly (Fig. 2). Low Gd doping content promoted the electro-catalytic activity of the anode. The optimal Gd doping content was $2 \%$ in terms of electro-catalytic performance. At the optimal doping content, COD decreased to $30.08 \mathrm{mg} / \mathrm{L}$ for $3 \mathrm{~h}$ treatment, with removal efficiency of $74.2 \%$. The electro-catalytic performance worsened when $\mathrm{Gd}$ doping content rose. Cell potential difference reflects the stability of the electrode. A small variation of cell potential difference was observed when Gd doping content was low, demonstrating well stability. Cell potential difference rose along with the process of electrolysis when $\mathrm{Gd}$ doping content increased, suggesting poor stability. With Gd doping content of $2 \%$, electro-catalytic activity and stability of the anode were both well. 

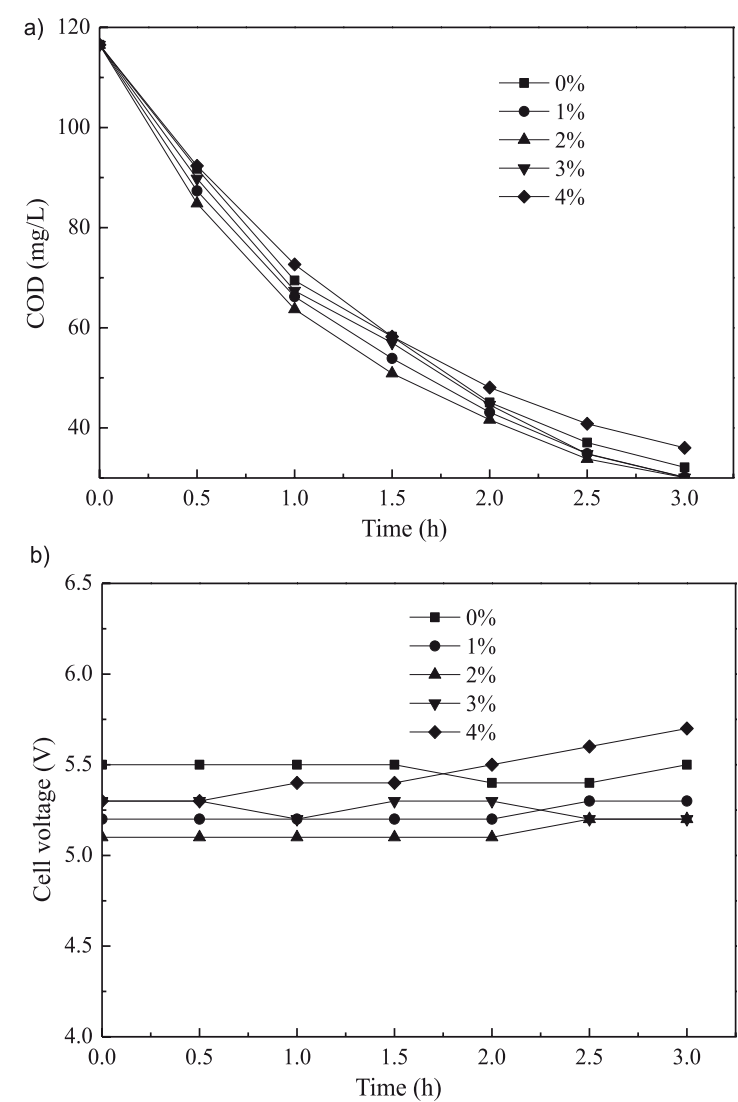

Fig. 2. Variations of COD and cell potential difference electrolyzed with anodes doping various amounts of Gd (a) COD removal, b) cell potential difference).

\section{Characterization of the Electrode}

\section{Polarization Curves}

Polarization curves reflect the characteristic relationship between electrode reaction rate and electrode potential. The tangent line of the later part crossed the abscissa axis (potential axis), and the abscissa value of the intersection was the oxygen evolution potential of the electrode.

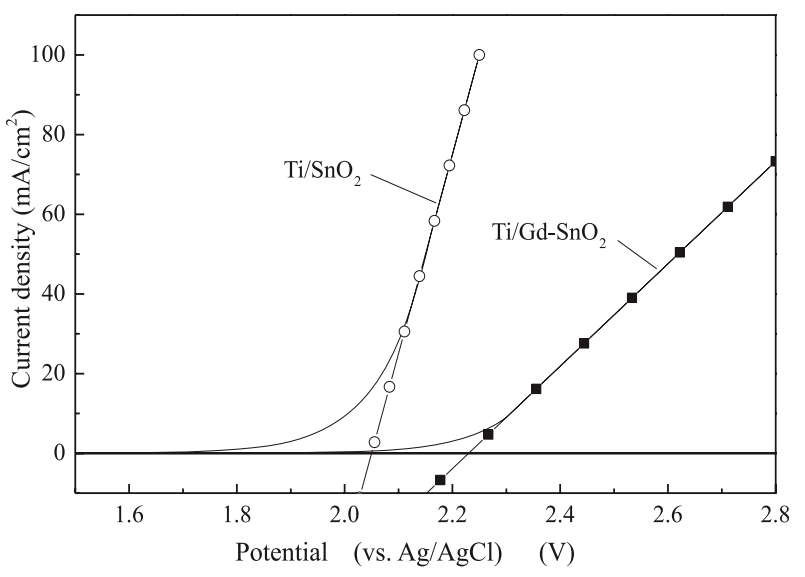

Fig. 3. Polarization curve of the electrodes.
The oxygen evolution potential of the $\mathrm{Ti} / \mathrm{SnO}_{2}$ anode was $2.05 \mathrm{~V}$ (vs. $\mathrm{Ag} / \mathrm{AgCl}$ ), while the oxygen evolution potential of the $\mathrm{Ti} / \mathrm{Gd}-\mathrm{SnO}_{2}$ anode ascended to $2.23 \mathrm{~V}$ (vs. $\mathrm{AgAgCl}$ ) (Fig. 3), suggesting that the surface structure and morphology of the electrode changed after the Gd addition.

The degradation of organic compounds depended on the adsorptive hydroxyl radicals on the electrode surface, while oxygen evolution reaction was the main competitive side reaction in the electrolysis process, which could reduce current efficiency and the degradation rate. The higher the oxygen evolution potential, the greater the resistance of the oxygen evolution reaction and the harder
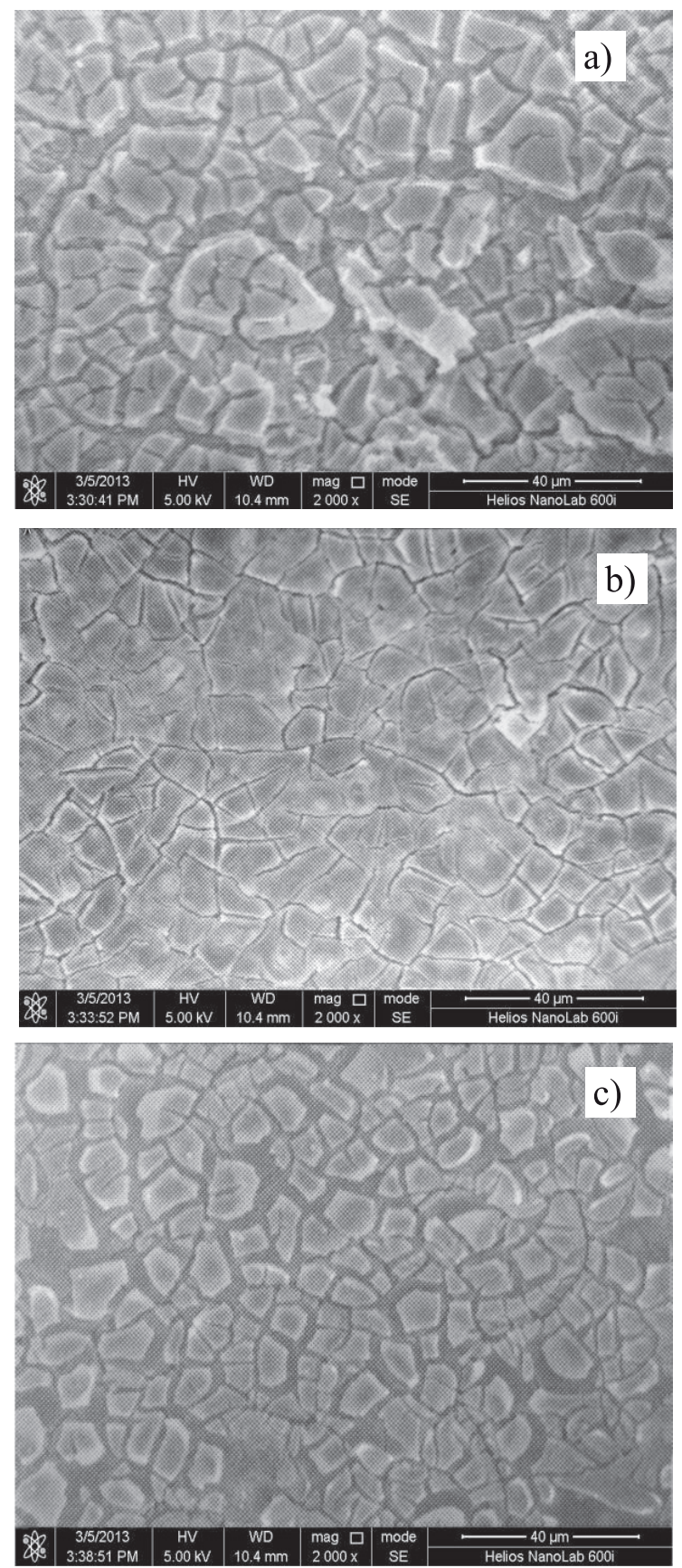

Fig. 4. SEM images of the anodes doped with various amounts of Gd (a. $0 \%$, b. $2 \%$, c. $4 \%$ ). 
it occurred. Therefore, the ability to generate hydroxyl radicals was enhanced and electrocatalytic performance was promoted. Moreover, the degradation rate on the electrode surface was faster than the mass transfer rate, resulting in a decrease of reactant concentration near the electrode and causing the fall of the current density. In order to maintain the defined current density, the electrode potential had to rise accordingly. The faster the reaction rate, the greater the elevated amount of electrode potential. The electrode reaction rate sped up with the increase of oxygen evolution potential [19].

\section{Scanning Electron Microscope (SEM)}

SEM was employed to analyze the morphology of the electrode surface (Fig. 4). Massive blocks with large cracks were agglomerated on the surface of the electrode without Gd doping. A uniform and compact film formed and covered the Ti support commendably when doping with adequate $\mathrm{Gd}(2 \%)$. Substantial tiny cracks lay on the surface layer of the anode with excessive Gd. The results demonstrated that a moderate amount of doped Gd prompted the refinement of crystalline grain. The homogeneous and compact oxide layer prevented the $\mathrm{Ti}$ substrate from being corroded into titanium dioxide by the active species generated on the electrode. The poor conductivity of titanium dioxide caused exfoliation of the oxide layer and deteriorated the stability of the electrode. Therefore, an adequate amount of doped Gd not only enhanced electrocatalytic performance but also improved the stability of the anode.

\section{X-Ray Diffraction Spectra}

We obtained the XRD spectra in Fig. 5 in order to compare the $\mathrm{Ti} / \mathrm{Gd}-\mathrm{SnO}_{2}$ and $\mathrm{Ti} / \mathrm{SnO}_{2}$ anodes. In contrast to the noise of the Ti substrate, the (110), (200), and (211) diffraction peaks of $\mathrm{SnO}_{2}$ in both anodes were still distinguished from the fingerprints of the XRD spectra. The dominant ingredient in the oxide coating was $\mathrm{SnO}_{2}$ in the tetragonal rutile crystalline phase, as

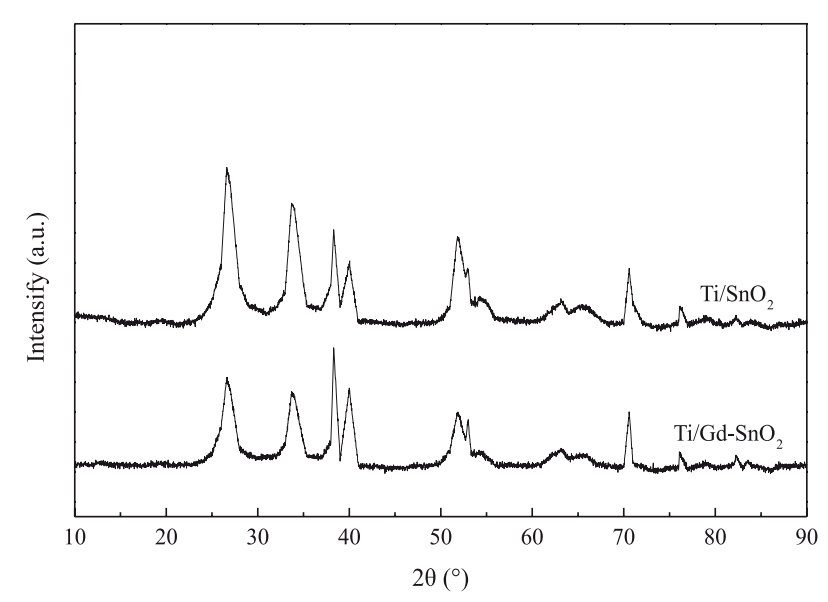

Fig. 5. X-ray diffraction patterns of the anodes.
Table 2. Analysis of XRD.

\begin{tabular}{|c|c|c|c|}
\hline \multirow{2}{*}{ Electrodes } & \multicolumn{2}{|c|}{ Cell parameters $(\mathrm{nm})$} & \multirow{2}{*}{$\begin{array}{c}\text { Grain size } \\
(\mathrm{nm})\end{array}$} \\
\cline { 2 - 3 } & $\mathrm{a}$ & $\mathrm{c}$ & \\
\hline $\mathrm{Ti} / \mathrm{SnO}_{2}$ & 0.47518 & 0.31986 & 11.26 \\
\hline $\mathrm{Ti} / \mathrm{Gd}-\mathrm{SnO}_{2}$ & 0.47792 & 0.32018 & 9.57 \\
\hline
\end{tabular}

analyzed from diffraction fingerprints. And crystal growth was fine. We did note find diffraction peaks of compounds containing $\mathrm{Sb}$ and $\mathrm{Gd}$, and deducing oxides containing $\mathrm{Sb}$ and $\mathrm{Gd}$ were not generated in the thermal process. This suggests that $\mathrm{Sb}$ and $\mathrm{Gd}$ were mixed into the $\mathrm{SnO}_{2}$ lattice by means of displacement or embedding. Diffraction intensity declined and the diffraction peaks broadened after $\mathrm{Gd}$ addition, for the reason that the oxides were formed before the annealed process and changed from the amorphous phase to the crystalline phase with increasing temperatures. The crystallite sizes were estimated by Scherrer equation on the (101) peak. And the detail information was listed in Table 2.

The grain size of anodes prepared by sol-gel method was at the nano level. The grain size descended in the thermal process after Gd was doped. The Gd doping changed the nucleation and growth rate of the crystal. The growth rate of the crystal was suppressed by doped Gd. Then the growth rate of the crystal was lower than the nucleation rate, leading to the diminution of grain size. Compared with the process of thermal decomposition, precursor conversion into oxide occurred during the reflux stage and most of the $\mathrm{M}-\mathrm{O}$ bonds were formed before the calcination step in the sol-gel process [20]. Whatever electrochemical combustion or electrochemical conversion, both demand a great deal of active sites. The active site with high surface energy reacts readily with other atoms to generate stable compounds. The electrode is essentially one kind of solid catalyst, without adjacent atoms on the outward side of the surface. Some chemical bonds toward the space turn into "dangling bonds" that are unsaturated and chemically active. The diminution of grain size supplied more active sites on the electrode surface. Therefore, the doped Gd enhanced the catalytic activity of the anode. In addition, the expansion of the unit cell was observed from the unit cell parameters. The displacement of $\mathrm{Sn}^{2+}$ (ion size $0.071 \mathrm{~nm}$ ) by $\mathrm{Gd}^{3+}$ (ion size $0.094 \mathrm{~nm}$ ) may be the key reason for the expansion.

\section{Electro-Catalytic Performance}

\section{TOC Removal}

The anode employed in the treatment of coal chemical industry wastewater was prepared at a sintering temperature of $750^{\circ} \mathrm{C}$ with $2 \% \mathrm{Gd}$ doping. TOC removal efficiency was employed to assess the mineralization rate of organic contamination and investigate the ability to decompose organics of the anode. 

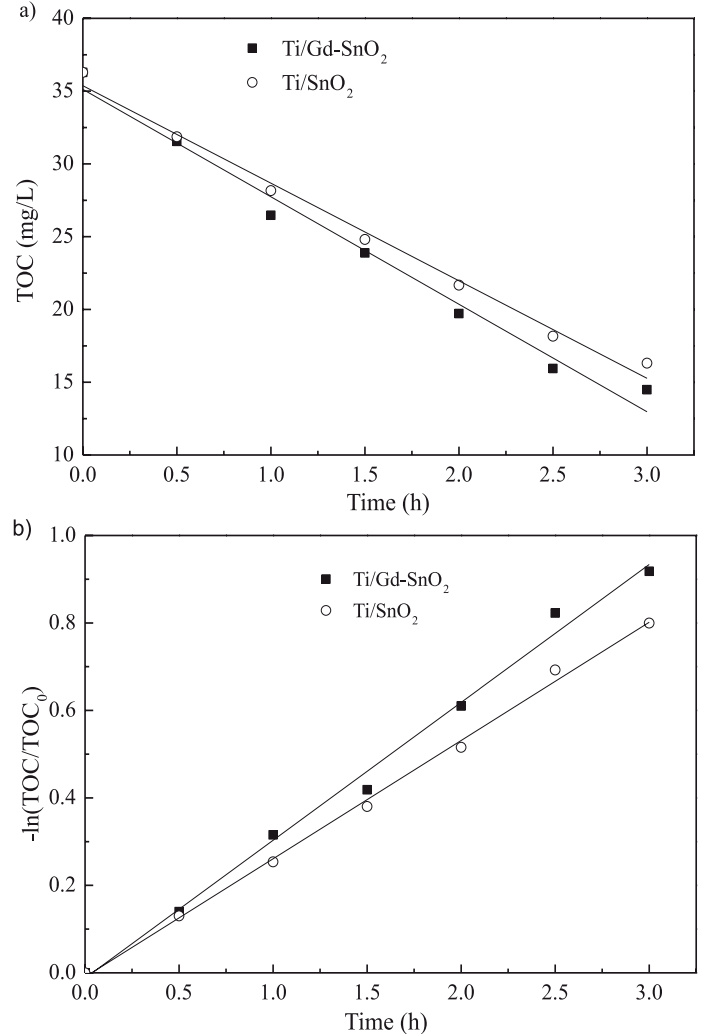

Fig. 6. Kinetics fitting in terms of TOC degradation (a) Pseudo zero-order kinetics fitting, b) Pseudo first-order kinetics fitting).

TOC in the effluent treated with the $\mathrm{Ti} / \mathrm{Gd}-\mathrm{SnO}_{2}$ anode was $14.49 \mathrm{mg} / \mathrm{L}$ for $3 \mathrm{~h}$ electrolysis, with removal efficiency of $60.1 \%$ (Fig. 6a), while TOC removal efficiency was $55.1 \%$ electrolyzed with an anode without $\mathrm{Gd}$ doping. The electro-catalytic performance of the $\mathrm{SnO}_{2}$ anode was enhanced significantly after an adequate amount of Gd doping. The removal of TOC reflected the amount of organic compound that completely mineralized in the wastewater. Electrochemical combustion was heightened due to the doped Gd.

Both pseudo zero-order and first-order fitting were well with linear correlation (Fig. 6, Table 3). Reaction rate constant $(k)$ can characterize the electro-catalytic activity of the electrode. The reaction rate constant of $\mathrm{SnO}_{2}$ anode doping adequate Gd was larger than that of the anode without $\mathrm{Gd}$, indicating that doping $\mathrm{Gd}$ accelerated the reaction rate of organic degradation and improved electrocatalytic activity. Both pseudo zero- and first-order fittings showed good correlation as judged from the squared correlation coefficient $\left(R^{2}\right)$. The squared correlation

Table 3. Kinetic parameters of TOC degradation.

\begin{tabular}{|c|c|c|c|c|}
\hline \multirow{2}{*}{ Electrode } & \multicolumn{2}{|c|}{ Pseudo zero-order } & \multicolumn{2}{|c|}{ Pseudo first-order } \\
\hline & $k$ & $R^{2}$ & $k$ & $R^{2}$ \\
\hline $\mathrm{Ti} / \mathrm{SnO}_{2}$ & 6.70214 & 0.99126 & 0.27039 & 0.99740 \\
\hline $\mathrm{Ti} / \mathrm{Gd}-\mathrm{SnO}_{2}$ & 7.38357 & 0.98389 & 0.31529 & 0.99341 \\
\hline
\end{tabular}

coefficient of pseudo first-order kinetic fitting was a little higher than that of pseudo zero-order kinetic fitting, deducing that electrolysis reaction was between pseudo zero-order and first-order kinetics and more inclined to the latter.

When the degradation rate of organics reacting on the electrode surface is fast enough, mass transfer becomes a rate-limiting step and electrolysis shows pseudo firstorder kinetics. In contrast, the Faraday electrolysis process changes into a rate-limiting step when reaction rate on the electrode surface is slower than mass transfer rate, presenting pseudo zero-order kinetics [21]. Electrolysis is more inclined to pseudo first-order kinetics, suggesting that mass transfer was the rate-determining step in advanced treatment of coal chemical industry wastewater. The major mass transfer mode in the liquid phase includes diffusion, migration, and conversion - all of which are functional in the electro-catalytic reaction [22]. Diffusion was the dominant method of mass transfer on the electrode surface. A reactant was consumed in the electrode reaction and then concentration difference of the reactant emerged between the electrode surface and the liquid bulk, forming the driving force of diffusion. Diffusion flux is proportional to the concentration gradient according to Fick's first law. The concentration of residual pollutant in the biologically pretreated wastewater was very low, resulting in a lower concentration difference and mass transfer rate. The low mass transfer rate made it the rate-determining step, being inclined to pseudo first-order kinetics.

\section{Chroma and UV254 Removal}

The value of UV254 demonstrates the content of aromatic compounds containing $\mathrm{C}=\mathrm{C}$ and $\mathrm{C}=\mathrm{O}$ bonds. Chroma is a sensory indicator of water quality. The performance of UV254 and chroma removal for $3 \mathrm{~h}$ electrolysis is listed in Table 4.

The removal efficiency of UV254 and chroma were $87 \%$ and $81 \%$, respectively, by electrolysis with the $\mathrm{Ti} / \mathrm{Gd}_{-} \mathrm{SnO}_{2}$ anode. The result illustrates that the $\mathrm{Ti} / \mathrm{Gd}_{-} \mathrm{SnO}_{2}$ anode was competent and that electrolysis was an effective method for advanced treatment of coal chemical industry wastewater.

\section{The Ability to Generate Free Radicals}

Electro-catalytic degradation of organic compounds comprised direct and indirect oxidation processes. Direct

Table 4. The performance of UV254 and chroma removal.

\begin{tabular}{|c|c|c|c|}
\hline & Influent & Effluent & $\begin{array}{c}\text { Removal } \\
\text { efficiency (\%) }\end{array}$ \\
\hline UV254 & $0.948 \pm 0.071^{\text {a }}$ & $0.114 \pm 0.042$ & $87.97 \pm 4.43$ \\
\hline Chroma & $98 \pm 2.6$ & $18 \pm 1.8$ & $81.63 \pm 3.68$ \\
\hline
\end{tabular}

a. values represent the average value \pm standard deviation of data obtained from five parallel tests. 


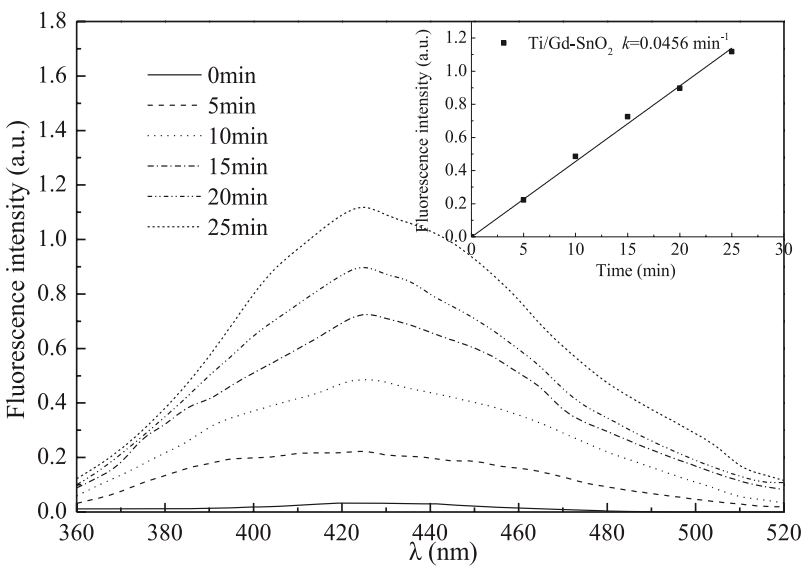

Fig. 7. Fluorescence spectra of effluent electrolyzed with $\mathrm{Ti} / \mathrm{Gd}-\mathrm{SnO}_{2}$ anode.

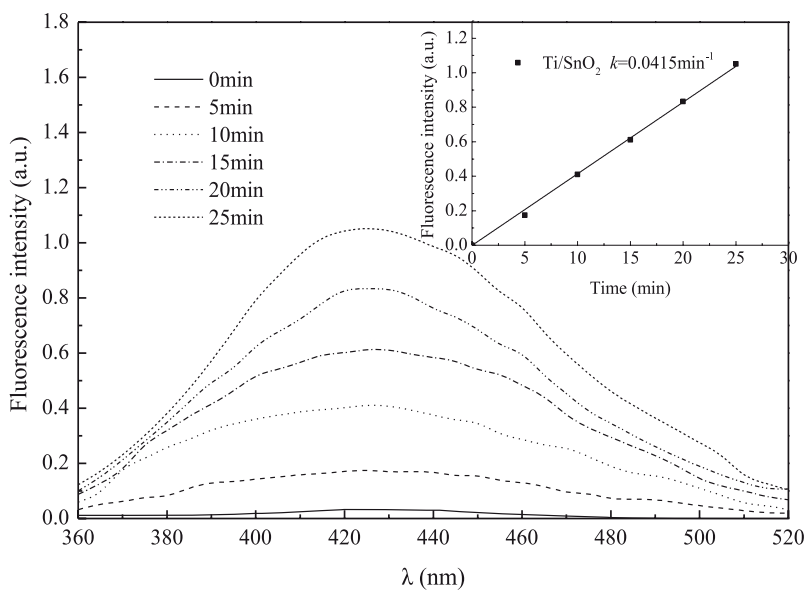

Fig. 8. Fluorescence spectra of effluent electrolyzed with $\mathrm{Ti} / \mathrm{SnO}_{2}$ anode.

oxidation was the Faraday process in which organic compounds directly lost electrons on the electrode surface. Indirect oxidation was mainly the oxidation reaction between organic compounds and active species formed on the electrode surface. The main active species was hydroxyl radicals $(\cdot \mathrm{OH})$. As the active group generated in AOPs, hydroxyl radicals play a vital contribution to the degradation of organics. The ability to produce $\cdot \mathrm{OH}$ was considered to be the index of an electrode to appraise its electro-catalytic performance. Terephthalic acid and $\cdot \mathrm{OH}$ react rapidly into 2-hydroxy terephthalic acid, which generates fluorescence emissions with the wavelength of $425 \mathrm{~nm}$ after an excitation by UV of $315 \mathrm{~nm}$. The evolution of fluorescence intensity indirectly reflected the generation content of hydroxyl radicals during the electrolysis process.

The fluorescence intensity ascended during the electrolysis process, as observed in both electrolyzers with $\mathrm{Ti} / \mathrm{Gd}-\mathrm{SnO}_{2}$ and $\mathrm{Ti} / \mathrm{SnO}_{2}$ anodes. A linear relationship was obtained between fluorescence intensity and time, demonstrating that the generation of hydroxyl radicals
Table 5. High current accelerated life test.

\begin{tabular}{|c|c|c|c|}
\hline $\begin{array}{c}\text { Current } \\
\text { density } \\
\left(\mathrm{mA} / \mathrm{cm}^{2}\right)\end{array}$ & $\begin{array}{c}\text { Actual current } \\
\text { density } \\
\left(\mathrm{mA} / \mathrm{cm}^{2}\right)\end{array}$ & $\begin{array}{c}\text { Accelerated } \\
\text { life } \\
(\mathrm{h})\end{array}$ & $\begin{array}{c}\text { Actual service } \\
\text { life } \\
(\mathrm{d})\end{array}$ \\
\hline 300 & 15 & 19.7 & 328.7 \\
\hline
\end{tabular}

conformed to pseudo zero-order kinetics. The generation of hydroxyl radicals sped up after Gd doping, illustrating that electro-catalytic activity was enhanced. The result was consistent with that of TOC degradation.

\section{Stability of the Anode}

The measurement of stability employed a high current accelerated life test. Then the lifespan of the electrode was estimated according to empirical formula (3):

$$
t=\left(A_{1} / A\right)^{2} \times t_{1}
$$

...where $A_{1}$ is the current density in the accelerated life test, $A$ is the actual current density, and $t_{1}$ is the lifespan obtained in the accelerated life test. The result of the test is listed in Table 5.

The actual service life of the prepared $\mathrm{Ti} / \mathrm{Gd}-\mathrm{SnO}_{2}$ anode was long enough and reacted to $328.7 \mathrm{~d}$, which provided favorable conditions for the practical application of the anode.

Electro-catalysis with the $\mathrm{Ti} / \mathrm{Gd}-\mathrm{SnO}_{2}$ anode exhibited excellent performance in the advanced treatment of the wastewater, and the $\mathrm{Ti} / \mathrm{Gd}-\mathrm{SnO}_{2}$ anode showed good stability. In addition, when four pairs of electrodes were employed in the electro-catalysis system, power consumption per ton of wastewater was $1.2 \mathrm{kWh}$ with effluent TOC and COD concentrations of 14.49 and $30.08 \mathrm{mg} / \mathrm{L}$. The results demonstrated that electrocatalysis with the $\mathrm{Ti} / \mathrm{Gd}-\mathrm{SnO}_{2}$ anode could serve as a technically feasible and cost-effective method with potential applications for the advanced treatment of coal chemical industry wastewater.

\section{Conclusions}

The optimal sintering temperature and doped $\mathrm{Gd}$ content of electrode preparation were $750^{\circ} \mathrm{C}$ and $2 \%$, respectively, in terms of both electro-catalytic performance and stability. A uniform and compact film formed and covered the Ti support commendably after adequate $\mathrm{Gd}$ addition (2\%), which enhanced anode stability. Gd mixed into the $\mathrm{SnO}_{2}$ lattice by means of displacement suppressed the growth of $\mathrm{SnO}_{2}$ crystalline grain. The diminution of grain size supplied more active sites on the electrode surface. The electrolysis reaction of TOC degradation with the $\mathrm{Ti} / \mathrm{Gd}-\mathrm{SnO}_{2}$ anode was between pseudo zeroand first-order kinetics, and more inclined to the latter. Mass transfer was the rate-determining step. The doped 
Gd accelerated the generation rate and content of hydroxyl radicals, and therefore improved electro-catalytic activity. The removal efficiencies of UV254 and chroma were $87 \%$ and $81 \%$ in electrolysis with the $\mathrm{Ti} / \mathrm{Gd}-\mathrm{SnO}_{2}$ anode. The study demonstrated that the prepared $\mathrm{Ti} / \mathrm{Gd}-\mathrm{SnO}_{2}$ anode was competent and that electrolysis with the anode could serve as a technically feasible method with potential application for the advanced treatment of coal chemical industry wastewater.

\section{Acknowledgements}

This study was financially supported by the Natural Science Foundation of Hunan Province, China (No. 2016JJ6041), the scientific research project of the Hunan Provincial Education Department (No. 15C0556), and the Zhejiang Provincial Natural Science Foundation of China (No. LQ17E080008).

\section{References}

1. HOU B.L., HAN H.J., JIA S.Y., ZHUANG H.F., ZHAO Q., XU P. Effect of alkalinity on nitrite accumulation in treatment of coal chemical industry wastewater using moving bed biofilm reactor. Journal of Environmental Sciences-China, 26 (5), 1014, 2014.

2. FELFOLDI T., SZEKELY A.J., GORAL R., BARKACS K., SCHEIRICH G., ANDRAS J., RACZ A., MARIALIGETI $\mathrm{K}$. Polyphasic bacterial community analysis of an aerobic activated sludge removing phenols and thiocyanate from coke plant effluent. Bioresource Technology, 101 (10), 3406, 2010.

3. HOU B., HAN H., ZHUANG H., XU P., JIA S., LI K. A novel integration of three-dimensional electro-Fenton and biological activated carbon and its application in the advanced treatment of biologically pretreated Lurgi coal gasification wastewater. Bioresource Technology, 196, 721, 2015.

4. ZHANG C., JIANG Y.H., LI Y.L., HU Z.X., ZHOU L., ZHOU M.H. Three-dimensional electrochemical process for wastewater treatment: A general review. Chemical Engineering Journal, 228, 455, 2013.

5. ELEOTERIO I.C., FORTI J.C., DE ANDRADE A.R. Electrochemical Treatment of Wastewater of Veterinary Industry Containing Antibiotics. Electrocatalysis, 4 (4), 283, 2013.

6. HAMMAMI S., OTURAN M.A., OTURAN N., BELLAKHAL N., DACHRAOUI M. Comparative mineralization of textile dye indigo by photo-Fenton process and anodic oxidation using boron-doped diamond anode. Desalination and Water Treatment, 45 (1-3), 297, 2012.

7. HOU B., HAN H., JIA S., ZHUANG H., XU P., WANG D. Heterogeneous electro-Fenton oxidation of catechol catalyzed by nano- $\mathrm{Fe}_{3} \mathrm{O}_{4}$ : kinetics with the Fermis s equation. Journal of the Taiwan Institute of Chemical Engineers, 56, 138, 2015.

8. HOU B., HAN H., JIA S., ZHUANG H., XU P., LI K. Three-dimensional heterogeneous electro-Fenton oxidation of biologically pretreated coal gasification wastewater using sludge derived carbon as catalytic particle electrodes and catalyst. Journal of the Taiwan Institute of Chemical Engineers, 60, 352, 2016.

9. BERGMANN M.E.H., KOPARAL A.S., IOURTCHOUK T. Electrochemical Advanced Oxidation Processes, Formation of Halogenate and Perhalogenate Species: A Critical Review. Critical Reviews in Environmental Science and Technology, 44 (4), 348, 2014.

10. HAN W.Q., CHEN Y., WANG L.J., SUN X.Y., LI J.S. Mechanism and kinetics of electrochemical degradation of isothiazolin-ones using $\mathrm{Ti} / \mathrm{SnO}_{2}-\mathrm{Sb} / \mathrm{PbO}_{2}$ anode. Desalination, 276 (1-3), 82, 2011.

11. GE J., YAO H.B., HU W., YU X.F., YAN Y.X., MAO L.B., LI H.H., LI S.S., YU S.H. Facile dip coating processed graphene $/ \mathrm{MnO}_{2}$ nanostructured sponges as high performance supercapacitor electrodes. Nano Energy, 2 (4), 505, 2013.

12. TORRES-MARTINEZ L.M., GOMEZ R., VAZQUEZCUCHILLO O., JUAREZ-RAMIREZ I., CRUZ-LOPEZ A., ALEJANDRE-SANDOVAL F.J. Enhanced photocatalytic water splitting hydrogen production on $\mathrm{RuO}_{2} / \mathrm{La} \mathrm{NaTaO}$ prepared by sol-gel method. Catalysis Communications, 12 (4), 268, 2010.

13. VELICHENKO A.B., GIRENKO D.V., DANILOV F.I. The mechanism of lead dioxide electrodeposition on a platinum electrode. Russian Journal of Electrochemistry, 33 (1), 96, 1997.

14. TRIVEDIP., GUPTAP., SRIVASTAVAS., JAYAGANTHAN R., CHANDRA R., ROY P. Characterization and in vitro biocompatibility study of Ti-Si-N nanocomposite coatings developed by using physical vapor deposition. Applied Surface Science, 293, 143, 2014.

15. CUI Y.H., FENG Y.J., LIU J.F., REN N.Q. Comparison of various organic compounds destruction on rare earths doped $\mathrm{Ti} / \mathrm{Sb}-\mathrm{SnO}_{2}$ electrodes. Journal of Hazardous Materials, 239, 225, 2012.

16. SANTOS D.M.F., SEQUEIRA C.A.C., MACCI D., SACCONE A., FIGUEIREDO J.L. Platinum-rare earth electrodes for hydrogen evolution in alkaline water electrolysis. International Journal of Hydrogen Energy, 38 (8), 3137, 2013.

17. KONG J., SHI S., KONG L., ZHU X., NI J. Preparation and characterization of $\mathrm{PbO}_{2}$ electrodes doped with different rare earth oxides. Electrochimica Acta, 53 (4), 2048, 2007.

18. CUI Y.H., FENG Y.J., LIU Z.Q. Influence of rare earths doping on the structure and electro-catalytic performance of $\mathrm{Ti} / \mathrm{Sb}-\mathrm{SnO}_{2}$ electrodes. Electrochimica Acta, 54 (21), 4903, 2009.

19. TROTOCHAUD L., BOETTCHER S.W. Precise oxygen evolution catalysts: Status and opportunities. Scripta Materialia, 74, 25, 2014.

20. LASSALI T.A.F., BOODTS J.F.C., BULHOES L.O.S. Effect of Sn-precursor on the morphology and composition of $\mathrm{Ir} 0.3 \mathrm{Sn} 0.7 \mathrm{O}_{2}$ oxide films prepared by sol-gel process. Journal of Non-Crystalline Solids, 273 (1-3), 129, 2000.

21. BIAN Z.Y., BIAN Y., WANG H., PANG L., DING A.Z. Electrocatalytic degradation kinetic of 4-chlorophenol by the $\mathrm{Pd} / \mathrm{C}$ gas-diffusion electrode system. Water Science and Technology, 67 (8), 1873, 2013.

22. COLLI A.N., BISANG J.M. Mass-transfer characterization in a parallel-plate electrochemical reactor with convergent flow. Electrochimica Acta, 113, 575, 2013. 